\title{
Plasma concentrations of gonadotrophins, preovulatory follicular development and luteal function associated with bovine follicular fluid-induced delay of oestrus in heifers*
}

\author{
S. M. Quirk and J. E. Fortune \\ Section of Physiology in the Division of Biological Sciences, Department of Physiology in the College \\ of Veterinary Medicine, and Women's Studies Program in the College of Arts and Sciences, \\ Cornell University, Ithaca, NY 14853, U.S.A.
}

\begin{abstract}
Summary. In Exp. 1, injections of $10 \mathrm{ml}$ bovine follicular fluid (bFF, i.v. or s.c.), given twice daily for 3 days after injection of a luteolytic dose of PGF-2 $\alpha$, delayed the onset of oestrus in 3 of 6 heifers to 8 or 9 days after PGF-2 $\alpha$, as compared with 2 or 3 days after PGF- $2 \alpha$ in control heifers. Mean plasma concentrations of FSH and LH during the injection period were not different from those in saline-injected heifers. In Exp. 2, i.v. injections of $20 \mathrm{ml} \mathrm{bFF}$ twice daily for 3 days uniformly delayed oestrus to 8 days after PGF- $2 \alpha(\mathrm{N}=4)$ and injections of $20 \mathrm{ml}$ bFF i.v. every $6 \mathrm{~h}$ for $24 \mathrm{~h}$ on the day of PGF- $2 \alpha$ injection delayed oestrus to $5 \cdot 0 \pm 0.6$ days after PGF- $2 \alpha$ as compared with $2 \cdot 8 \pm 0.3$ days for control heifers. In both treatment groups, plasma concentrations of FSH were suppressed during the injection period and increased transiently after treatment, but plasma concentrations of LH during the injection period were not different from those of control heifers. Plasma levels of oestradiol in heifers given bFF remained basal for 2 or 3 days after treatment, then increased several days before the delayed oestrus, in a manner similar to that in control heifers, and elicited normal preovulatory surges of LH and FSH. Plasma concentrations of progesterone and the length of the next oestrous cycle were normal, indicating formation of functional corpora lutea. Therefore, bFF treatments appear to delay oestrus by selectively suppressing plasma $\mathrm{FSH}$, without affecting $\mathrm{LH}$, and delaying the development of the preovulatory follicle. These results suggest that FSH may be critical to support the growth and development of the preovulatory follicle after luteolysis in cows.
\end{abstract}

\section{Introduction}

FSH and LH are essential for growth and maturation of ovarian follicles (Richards, 1980), but their relative roles during the final stages of follicular development in cattle have not been clearly defined. In cattle and sheep final growth and maturation of preovulatory follicles occur during a short follicular phase lasting several days after luteolysis (Hansel \& Convey, 1983). After luteolysis, basal plasma concentrations of LH and the frequency of pulsatile LH release increase (Rahe, Owens, Fleeger, Newton \& Harms, 1980; Goodman et al., 1981; Schallenberger, Schams, Bullermann \& Walters, 1984). Increased stimulation by LH is thought to promote preovulatory follicular development (McNatty, Gibb, Dobson \& Thurley, 1981; McNeilly, Fraser \& Baird, 1984). In contrast to changes in plasma concentrations of LH, concentrations of FSH decline after luteolysis in cows (Butler, Katz, Arriola, Milvae \& Foote, 1983; Schallenberger et al., 1984) and

*Reprint requests to Dr J. E. Fortune, Department of Physiology, College of Veterinary Medicine, Cornell University, Ithaca, NY 14853, U.S.A. 
sheep (L'Hermite, Niswender, Reichert \& Midgley, 1972), suggesting that increases in FSH are not needed for the final stages of follicular development. In addition, ovulation can be induced in anoestrous ewes by injections of LH (McNeilly, O'Connell \& Baird, 1982). These results indicate that plasma levels of FSH during anoestrus are sufficient to allow preovulatory follicular development, but that LH support is inadequate. These studies have supported the concept that LH has a critical function in stimulation of preovulatory follicular development after luteolysis, whereas the role of FSH is more permissive. However, direct evidence for this idea is lacking.

Follicular fluid from all species examined contains a protein, inhibin or folliculostatin, which selectively depresses plasma concentrations of FSH and inhibits secretion of FSH by pituitary cells in vitro (Channing et al., 1982; Grady, Charlesworth \& Schwartz, 1982). Injections of bovine follicular fluid during the follicular phase of the oestrous cycle in heifers and ewes lengthened the interval from luteolysis to oestrus (Miller, Critser, Rowe \& Ginther, 1979) and subsequent studies with ewes showed that plasma concentrations of FSH decreased during treatment (Miller, Critser \& Ginther, 1982; McNeilly, 1984). Injections of bovine follicular fluid to ovariectomized heifers, prepubertal heifers and cyclic heifers during the late luteal phase of the oestrous cycle decreased plasma concentrations of FSH, but did not alter plasma concentrations of LH (Ireland, Curato \& Wilson, 1983; Braun, Schams, Buck \& Leidl, 1983; Johnson, Smith \& Elmore, 1985). The aim of the present study was to determine whether treatment of heifers with bovine follicular fluid during the follicular phase of the oestrous cycle would selectively suppress plasma concentrations of FSH and, if so, whether this would alter preovulatory follicular development and/or subsequent luteal function.

\section{Materials and Methods}

Experiment 1. Nine Holstein heifers with normal oestrous cycles were injected with $25 \mathrm{mg}$ prostaglandin (PG) F-2 $\alpha$ i.m. (Lutalyse; Upjohn Co., Kalamazoo, MI, U.S.A.) on Day 14, 15 or 16 of the oestrous cycle (Day $0=$ oestrus) to induce luteal regression. Heifers were injected with $10 \mathrm{ml}$ of charcoal-extracted bovine follicular fluid (bFF, preparation described below) or saline $(9 \mathrm{~g}$ $\mathrm{NaCl} / \mathrm{l}$ ) every $12 \mathrm{~h}$ for 3 days beginning at the time of PGF- $2 \alpha$ injection. Treated heifers were injected with bFF i.v. $(\mathrm{N}=3)$ or s.c. $(\mathrm{N}=3)$, and control heifers $(\mathrm{N}=3)$ were injected with saline i.v. Heifers were checked for oestrous activity twice daily. Blood samples were collected by jugular venepuncture 72 and $48 \mathrm{~h}$ before injection of PGF- $2 \alpha$, and then every $6 \mathrm{~h}$ from $24 \mathrm{~h}$ before injection of PGF- $2 \alpha$ until $48 \mathrm{~h}$ after heifers were in oestrus. Blood samples were collected daily throughout the oestrous cycle after treatment. Plasma was stored at $-20^{\circ} \mathrm{C}$ until assayed for FSH, LH and progesterone by radioimmunoassays (RIA).

Experiment 2. Twelve Holstein heifers with normal oestrous cycles were injected with $25 \mathrm{mg}$ PGF-2 $\alpha$ on Day 14 or 15 of the oestrous cycle. At 2 days before injection of PGF-2 $\alpha$, a Silastic medical-grade cannula (i.d. $0 \cdot 10 \mathrm{~cm}$; 0. d. $0.22 \mathrm{~cm}$; Dow Corning Corp., Midland, MI, U.S.A.) was inserted into the jugular vein of each heifer. Heifers were treated with i.v. injections of $20 \mathrm{ml}$ charcoal-extracted bFF $(\mathrm{N}=4)$ or saline $(\mathrm{N}=4)$ every $12 \mathrm{~h}$ for 3 days beginning at the time of PGF-2 $\alpha$ injection (total of 6 injections). Another group of heifers was treated with i.v. injections of $20 \mathrm{ml}$ bFF every $6 \mathrm{~h}$ for $24 \mathrm{~h}$ beginning $6 \mathrm{~h}$ before PGF- $2 \alpha$ injection $(\mathrm{N}=4$, total of 5 injections) to test the hypothesis that FSH is most critical for follicular development at the beginning of the follicular phase. Blood samples were taken from the cannulae every $2 \mathrm{~h}$ from $24 \mathrm{~h}$ before until $74 \mathrm{~h}$ after PGF- $2 \alpha$ treatment and then every $4 \mathrm{~h}$ until $48 \mathrm{~h}$ after oestrus. Cannulae were filled with heparin-saline (200 i.u./ml) after each sample. Cannulae were then removed and blood samples were collected daily by jugular venepuncture until the next oestrus. Heifers were checked for oestrus twice daily. Plasma concentrations of FSH, LH, progesterone and oestradiol-17 $\beta$ were determined by RIA. 
Preparation of charcoal-extracted bFF. Bovine follicular fluid was collected at a local slaughterhouse by aspiration of all visible follicles $<2.5 \mathrm{~cm}$ diameter (to exclude obviously cystic follicles). The follicular fluid was frozen on solid $\mathrm{CO}_{2}$ for transport to the laboratory and then stored at $-20^{\circ} \mathrm{C}$. Steroids were removed from bFF by a modification of the procedure used by Miller $e t$ al. (1979). The follicular fluid was stirred with $50 \mathrm{mg}$ charcoal $/ \mathrm{ml}$ (Norit-A, Fisher Scientific, Fair Lawn, NJ, U.S.A.) for $45 \mathrm{~min}$ at room temperature and centrifuged at $2000 \mathrm{~g}$ for $30 \mathrm{~min}$ at $4^{\circ} \mathrm{C}$. The supernatant was centrifuged at $12000 \mathrm{~g}$ for $30 \mathrm{~min}$ at $4^{\circ} \mathrm{C}$ and filtered through glass-fibre filter paper to remove charcoal particles. A different batch of bFF was used in each of the two experiments: charcoal extraction reduced concentrations of progesterone in bFF from 60.6 to $0.3 \mathrm{ng} / \mathrm{ml}$ and from 62.5 to $0.1 \mathrm{ng} / \mathrm{ml}$ in the batches of bFF used in Exps 1 and 2, respectively. Oestradiol concentrations in bFF were reduced from 61.4 to $0.06 \mathrm{ng} / \mathrm{ml}$ and from 39.6 to $0.04 \mathrm{ng} / \mathrm{ml}$ in Exps 1 and 2 , respectively.

Hormone assays. The limit of sensitivity of each RIA described below was determined by the concentration of hormone which depressed binding of the radioligand to $90 \%$ of the binding in buffer control tubes ( $100 \%$ binding). The intra-assay coefficient of variation $(\mathrm{CV})$ was calculated by averaging the $\mathrm{CV}$ for duplicate determinations of 20 randomly chosen samples in 4 or 5 assays for each hormone. Inter-assay $\mathrm{CV}$ was calculated by averaging the $\mathrm{CV}$ for 2 or 3 plasma pools run in duplicate in each assay.

Plasma concentrations of LH were measured by RIA (Niswender, Reichert, Midgley \& Nalbandov, 1969) using anti-ovine LH antiserum (GDN No. 15) supplied by Dr G. D. Niswender, highly purified ovine LH (LER-1056-C2) for radioiodination donated by Dr L.E. Reichert, Jr and bovine LH (NIH-LH-B9) as standard. The second antibody was goat anti-rabbit immunoglobulin $\mathrm{G}$ (Miles Laboratories, Elkhart, IN, U.S.A.). The sensitivity of the assay was $0.12 \mathrm{ng} \mathrm{LH}$ /assay tube. The intra-assay $C V$ was $7 \cdot 0 \%$ and the inter-assay $C V$ was $13 \cdot 8 \%$ (18 assays; average for 3 pools at 91,73 and $20 \%$ on the standard curve).

Plasma concentrations of FSH were measured by RIA (Bolt \& Rollins, 1983; Butler et al., 1983) using reagents obtained from the USDA Animal Hormone Program. Reagents included (1) specific antiserum directed against the $\beta$-subunit of highly purified bovine FSH (USDA-FSH-BP1 $\beta$ ), (2) purified bovine FSH (USDA-FSH-BP3) for radioiodination (using chloramine-T; Bolt \& Rollins, 1983), and (3) a standard preparation of bovine FSH (USDA-FSH-B1, with biological potency $1.7 \times$ NIH-FSH-B1). The second antibody was the same as that used in the RIA for plasma LH. The sensitivity of the assay was $0.9 \mathrm{ng} \mathrm{FSH} /$ assay tube $(3.0 \mathrm{ng} / \mathrm{ml})$. The intra-assay CV was $9.4 \%$ and the inter-assay CV was $12.8 \%$ (18 assays; average for 2 pools at $54 \%$ and $40 \%$ on the standard curve).

Plasma concentrations of progesterone were measured by a specific RIA (Beal, Milvae \& Hansel, 1980) with a sensitivity of $16 \mathrm{pg}$ /assay tube, an intra-assay CV of $8.7 \%$ and an inter-assay CV of $13.4 \%$ ( 9 assays; average for 2 pools at $73 \%$ and $32 \%$ on the standard curve). Progesterone was extracted from $100 \mu \mathrm{l}$ plasma with petroleum ether. Recovery of labelled progesterone added to cow plasma was $84 \cdot 3 \pm 0 \cdot 8 \%$ (s.e.m.; $N=50$ ) and the solvent blank was negligible. Values were not corrected for recovery.

Plasma concentrations of oestradiol-17 $\beta$ were measured using a modification of the extraction, purification, and RIA procedure of England, Niswender \& Midgley (1974). The antibody is highly specific for oestradiol-17ß (Korenman et al., 1974). Oestradiol was extracted from $2 \mathrm{ml}$ plasma by two successive extractions with $5 \mathrm{ml}$ diethyl ether. Extracts were chromatographed on Sephadex LH-20 columns equilibrated with benzene:methanol $(85: 15 \mathrm{v} / \mathrm{v})$. Recovery of $\left[{ }^{3} \mathrm{H}\right]$ oestradiol-17 $\beta$ (1200 c.p.m.) added to each sample before extraction was determined and used to correct for procedural losses. The recovery of labelled oestradiol was $82.3 \pm 0.9 \%$ (mean \pm s.e.m.; $N=150$ ) and the solvent blank was always $<0.5 \mathrm{pg} / \mathrm{ml}$. The radioligand used in the assay was oestradiol-17 $\beta-$ $\left[{ }^{125} \mathrm{I}\right]$ tyrosine methyl ester (Micromedic Systems, Horsham, PA, U.S.A.). Donkey anti-sheep gamma globulin (Cambridge Medical Diagnostics, Inc., Billerica, MA, U.S.A.) was used as the 
second antibody. The assay sensitivity was $0.6 \mathrm{pg} /$ assay tube $(0.9 \mathrm{pg} / \mathrm{ml})$. The intra-assay $\mathrm{CV}$ was $8 \cdot 1 \%$ and the inter-assay CV was $8.5 \%$ (4 assays; average of 3 pools at 42,27 and $12 \%$ on the standard curve).

Statistical analyses. The effects of treatments on the interval from injection of PGF- $2 \alpha$ to oestrus and to the preovulatory surges of LH and FSH and on length of the oestrous cycles after treatments were assessed by analysis of variance followed by linear contrasts to determine differences between individual treatments. Plasma concentrations of FSH, LH, oestradiol and progesterone in different treatment groups were compared by split-plot analysis of variance for repeated measurements over time (Gill, 1979). Analysis of variance was used to compare average concentrations of FSH before injection of PGF-2 $\alpha$ (mean concentrations in samples $-24 \mathrm{~h}$ to $0 \mathrm{~h}$ from PGF- $2 \alpha$ ) to mean concentrations 24 to $48 \mathrm{~h}$ after PGF- $2 \alpha$ and mean concentrations after termination of bFF injections.

\section{Results}

\section{Experiment 1}

Treatment of heifers with $10 \mathrm{ml}$ injections of bFF delayed oestrus from $2 \cdot 3 \pm 0 \cdot 3$ days (mean \pm s.e.m.) after PGF- $2 \alpha$ in control heifers to 8 days after PGF- $2 \alpha$ in 2 of 3 heifers given bFF injections i.v., and to 9 days in 1 of 3 heifers given bFF injections s.c. (Table 1). The remaining bFF-treated heifers were in oestrus 3 or 4 days after PGF-2 $\alpha$. Oestrus was therefore delayed in only 3 of the 6 heifers treated with bFF.

There were no differences in plasma concentrations of FSH or LH in bFF-treated and control heifers during the injection period $(P>0.05$, data not shown). All heifers had preovulatory surges of FSH and LH on the day of oestrus; in 3 heifers, therefore, preovulatory surges of FSH and LH were also delayed to 8 or 9 days after PGF-2 $\alpha$ treatment (Table 1). The length of the oestrous cycle (Table 1) and plasma concentrations of progesterone (data not shown) after treatment were similar

Table 1. Effect of $10 \mathrm{ml}$ injections of bovine follicular fluid (bFF, i.v. or s.c.) or saline (i.v.) every $12 \mathrm{~h}$ for 3 days (Exp. 1) on time to oestrus, time to the preovulatory LH/FSH surge, and length of the oestrous cycle after treatment in individual heifers

\begin{tabular}{lccc}
\hline Treatment & $\begin{array}{c}\text { Day of } \\
\text { oestrus } \dagger\end{array}$ & $\begin{array}{c}\text { Time from PGF-2 } \alpha \\
\text { to LH/FSH surge (h) }\end{array}$ & $\begin{array}{c}\text { Length of oestrous } \\
\text { cycle after treatment } \\
\text { (days) }\end{array}$ \\
\hline Saline & 2 & 72 & 25 \\
& 3 & 72 & 20 \\
& 2 & 54 & 19 \\
& & $* 66 \cdot 0 \pm 6 \cdot 0$ & $* 21 \cdot 3 \pm 1.9$ \\
\hline bFF, i.v. & 4 & 90 & 18 \\
& 8 & 192 & 21 \\
& 8 & 186 & 27 \\
\hline bFF, s.c. & 4 & $* 156 \cdot 0 \pm 33 \cdot 0$ & $* 22 \cdot 0 \pm 2 \cdot 6$ \\
& 3 & 96 & 30 \\
& 9 & 90 & 20 \\
& & 222 & 23 \\
& & $* 136 \cdot 0 \pm 43.0$ & $* 24.3 \pm 3.0$ \\
\hline
\end{tabular}

*Mean \pm s.e.m. There were no significant differences amongst means in the same vertical column $(P>0.05)$

†Days after injection of PGF-2 $\alpha$. 
in bFF-treated heifers and control heifers $(P>0.05)$, indicating that functional corpora lutea were formed in animals that exhibited delayed oestrus.

The inconsistent results obtained in this experiment led us to perform Exp. 2, in which the dose of bFF was doubled and blood samples were collected more frequently.

\section{Experiment 2}

Effects of bFF on the length of the oestrous cycle. In heifers treated with $20 \mathrm{ml}$ injections of bFF for 3 days, oestrus was uniformly delayed to 8 days after PGF- $2 \alpha$ treatment and preovulatory surges of LH and FSH occurred on the same day (Table 2). Oestrus and gonadotrophin surges were also delayed in heifers given more frequent injections of $20 \mathrm{ml} \mathrm{bFF}$ for 1 day but the response was more variable (5.0 \pm 0.6 days, mean \pm s.e.m.; Table 2$)$. One heifer in that group showed continuous oestrous activity between 5 and 9 days after PGF-2 $\alpha$ treatment and plasma concentrations of oestradiol (see below) suggested abnormal development of the preovulatory follicle. Oestrus was not detected in one heifer, but preovulatory surges of LH and FSH occurred between 6 and 7 days after PGF- $2 \alpha$.

Table 2. Effect of i.v. injections of $20 \mathrm{ml}$ bovine follicular fluid (bFF) or saline every $12 \mathrm{~h}$ for 3 days or $20 \mathrm{ml}$ bFF every $6 \mathrm{~h}$ for $\mathrm{l}$ day (Exp. 2) on time to oestrus, time to the preovulatory LH/FSH surge, and length of the oestrous cycle after treatment in individual heifers

\begin{tabular}{lccc}
\hline Treatment & $\begin{array}{c}\text { Day of } \\
\text { oestrus } \dagger\end{array}$ & $\begin{array}{c}\text { Time from PGF-2 } \alpha \\
\text { to LH/FSH surge (h) }\end{array}$ & $\begin{array}{c}\text { Length of oestrous } \\
\text { cycle after treatment } \\
\text { (days) }\end{array}$ \\
\hline Saline & 3 & 68 & 22 \\
& 2 & 60 & 20 \\
& 3 & 78 & 19 \\
& 3 & 74 & 22 \\
& & $* 70 \cdot 0 \pm 3 \cdot 9^{\mathrm{a}}$ & $* 20 \cdot 8 \pm 0 \cdot 8^{\mathrm{a}}$ \\
\hline bFF, 3 days & 8 & 190 & 19 \\
& 8 & 202 & 21 \\
& 8 & 206 & 23 \\
& 8 & 202 & 20 \\
bFF, I day & 6 & $* 200 \cdot 0 \pm 3 \cdot 5^{\mathrm{c}}$ & $20 \cdot 8 \pm 0 \cdot 9^{\mathrm{a}}$ \\
& Not detected & 146 & 16 \\
& 4 & 166 & 23 \\
& $5 \ddagger$ & 94 & 269 \\
& & 138 & $* 19 \cdot 0 \pm 2 \cdot 1^{\mathrm{a}}$ \\
\hline
\end{tabular}

*Mean \pm s.e.m. Means in the same vertical column with different superscripts are different, $P<0.005$ (ANOVA).

$\dagger$ Days after injection of PGF-2 $\alpha$.

$\S$ Days from preovulatory $\mathrm{LH}$ surge to next oestrus.

$\ddagger$ Heifer showed oestrous behaviour $5,6,7,8$ and 9 days after PGF- $2 \alpha$.

TA corpus luteum was not formed; plasma concentrations of progesterone remained $<1 \mathrm{ng} / \mathrm{ml}$. Not included in the mean.

Effects of bFF on plasma concentrations of $\mathrm{LH}$ and FSH. Plasma concentrations of FSH in control heifers started to decline after luteolysis and were $20 \%$ lower between 24 and $48 \mathrm{~h}(P<0 \cdot 05)$ after injection of PGF-2 $\alpha$ when compared to pre-treatment concentrations (Figs 1a, 2a). In heifers treated with bFF for 3 days plasma levels of FSH were $28 \%$ lower $(P<0.05)$ than those in control heifers by $6 \mathrm{~h}$ after PGF-2 $\alpha$ (the time of the first injection of bFF). In heifers treated with bFF for 3 

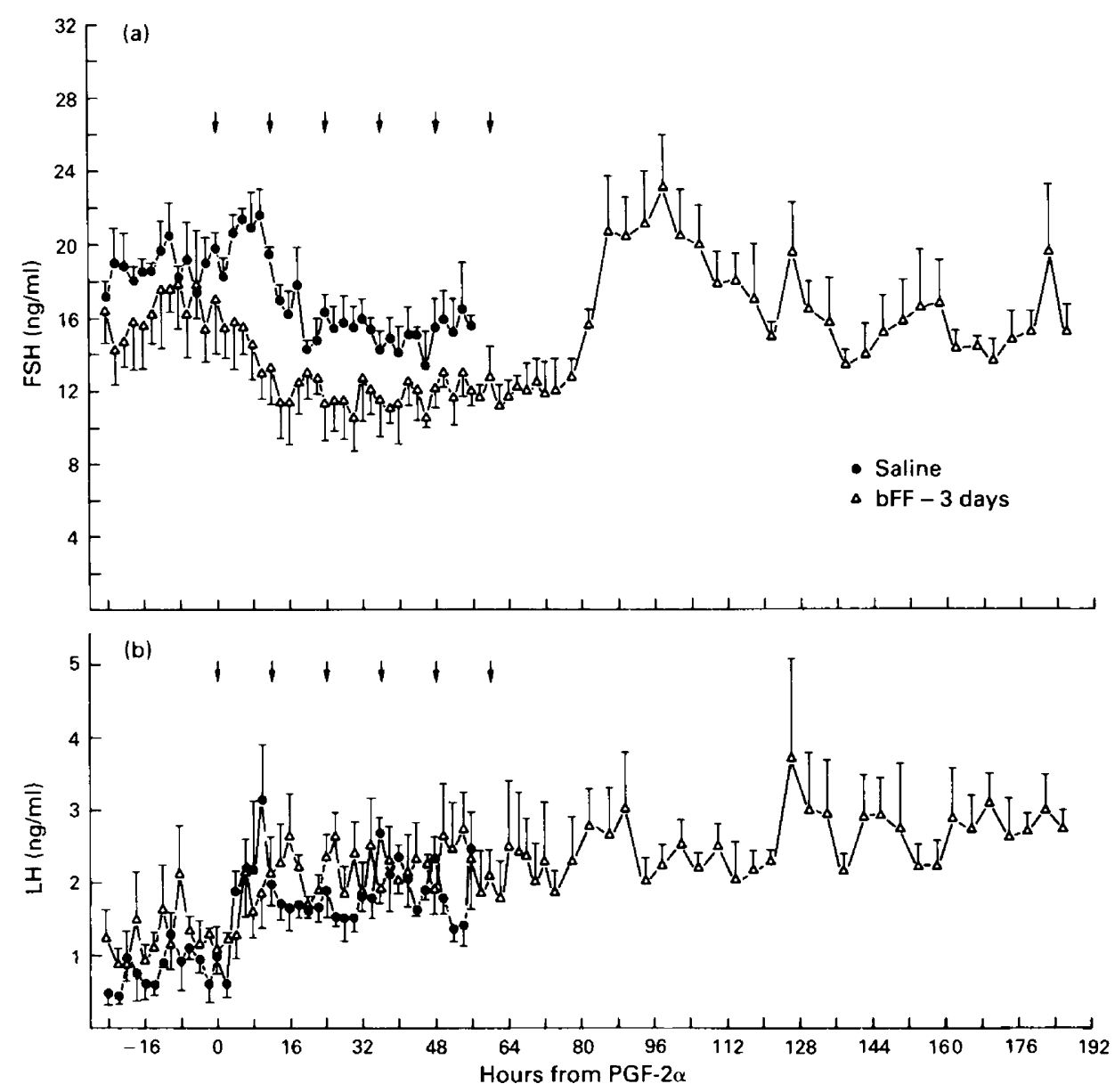

Fig. 1. Changes in plasma concentrations (mean \pm s.e.m.; $N=4$ ) of FSH (a) and $\mathrm{LH}$ (b) after injection of PGF-2 $\alpha(0 \mathrm{~h})$ in heifers treated with i.v. injections of $20 \mathrm{ml}$ saline or bovine follicular fluid (bFF) every $12 \mathrm{~h}$ for 3 days. Times of injections are indicated by arrows. Data for each treatment are shown until just before the time of preovulatory surges of gonadotrophins.

days plasma concentrations of FSH were $29 \%$ lower between 24 and $48 \mathrm{~h}$ after than before injection of PGF-2 $\alpha$ (Fig. la). Plasma concentrations of FSH remained lower in bFF-treated heifers than in control heifers throughout the injection period $(P<0.05)$, except for the period between 36 and $48 \mathrm{~h}$ after the beginning of treatment when differences were marginally significant $(P<0 \cdot 10)$. Plasma concentrations of FSH in heifers treated with bFF for 1 day were decreased relative to values in control heifers between 8 and $20 \mathrm{~h}$ after the first injection of bFF (2-14 h after PGF-2 $\alpha$; $P<0.05$ ), then increased before the last injection of $b F F$ and were no different from control values between 22 and $46 \mathrm{~h}$ ( $16-40 \mathrm{~h}$ after PGF-2 $\alpha ; P>0.05$; Fig. 2a). In heifers treated with bFF for 1 or 3 days, concentrations of FSH increased by $24 \mathrm{~h}$ after the last injection of bFF and remained elevated for $24-36 \mathrm{~h}$. During this $24-36 \mathrm{~h}$ period FSH values were similar to those before injection of PGF-2 $\alpha(P>0.05)$ in heifers treated with bFF for 3 days, but were higher than those before injection of PGF- $2 \alpha(P<0.05)$ in heifers treated with bFF for 1 day. After injection of PGF-2 $\alpha$, plasma concentrations of $\mathrm{LH}$ increased in a similar manner in the heifers treated with bFF and in control heifers (Figs 1b, 2b). 

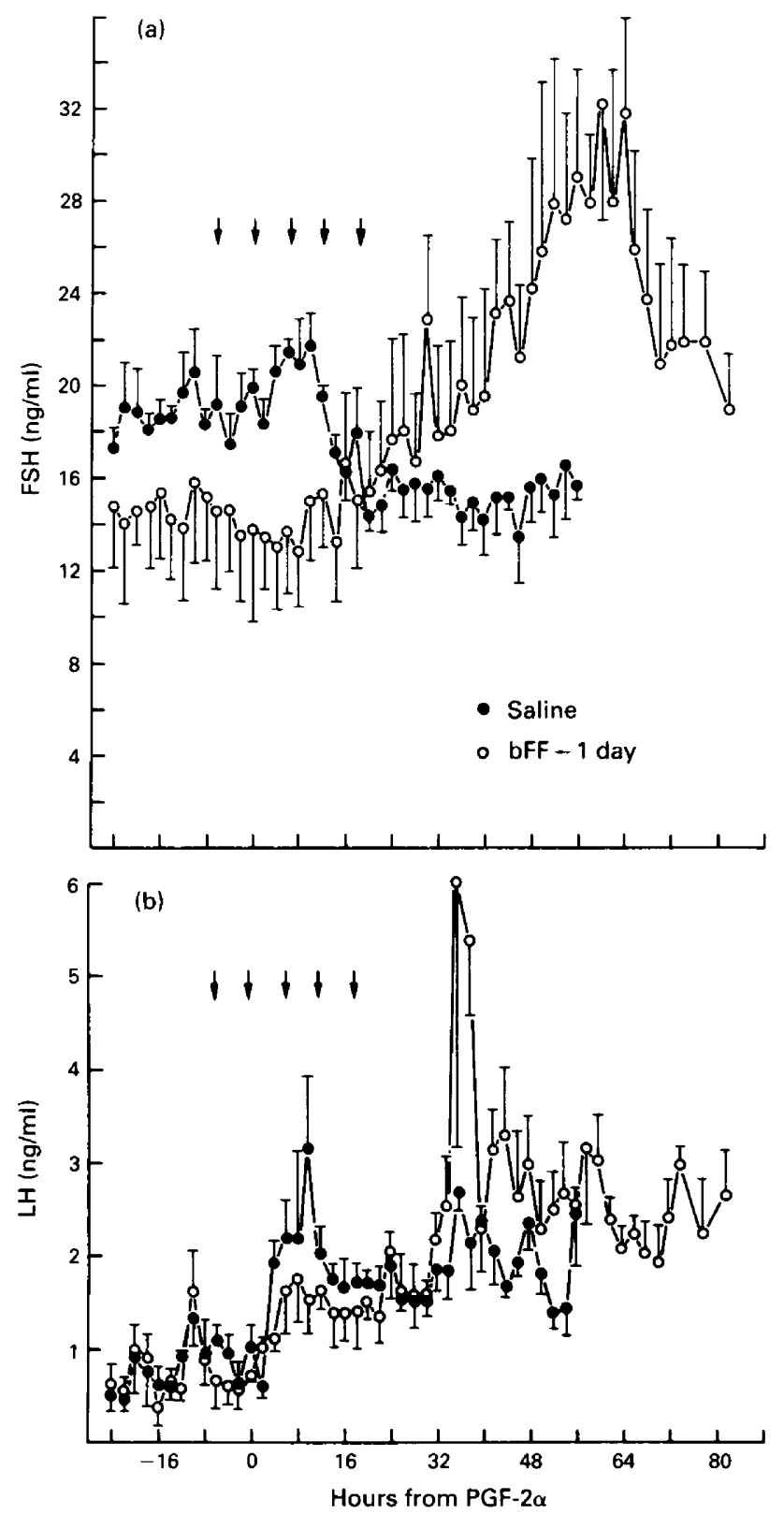

Fig. 2. Changes in plasma concentrations (mean \pm s.e.m.; $N=4$ ) of FSH (a) and LH (b) after injection of PGF- $2 \alpha(0 \mathrm{~h})$ in heifers treated with i.v. injections of $20 \mathrm{ml}$ saline (as in Fig. 1) or with $20 \mathrm{ml}$ bovine follicular fluid (bFF) every $6 \mathrm{~h}$ for 1 day. Times of injections are indicated by arrows. Data for each treatment are shown until just before the time of preovulatory surges of gonadotrophins.

Plasma concentrations of FSH and $\mathrm{LH}$ in control and bFF-treated heifers normalized to the time of the preovulatory LH surge are shown in Figs 3(a) and 3(b). Plasma concentrations of FSH around the time of the gonadotrophin surges were similar in control heifers and heifers treated with $\mathrm{bFF}$ for 3 days but were higher and more variable 2 days before the surge in heifers treated with 

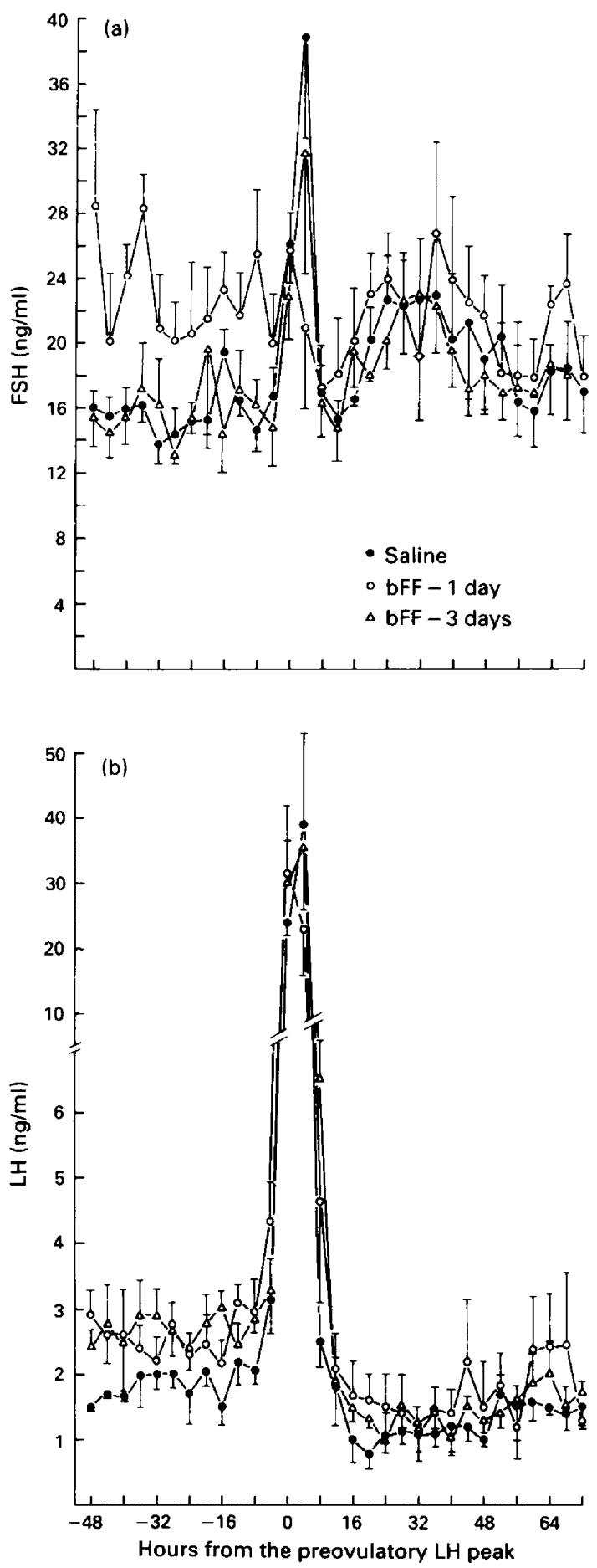

Fig. 3. Changes in plasma concentrations (mean \pm s.e.m.; $N=4$ ) of FSH (a) and LH (b) relative to the preovulatory peaks of $\mathrm{LH}(0 \mathrm{~h})$ in heifers treated with i.v. injections of $20 \mathrm{ml}$ saline or bovine follicular fluid (bFF) every $12 \mathrm{~h}$ for 3 days or $20 \mathrm{ml} \mathrm{bFF}$ every $6 \mathrm{~h}$ for 1 day. 



Fig. 4. Changes in plasma concentrations of oestradiol after PGF-2 $\alpha$-induced luteolysis (Day 0 ) in individual heifers treated with i.v. injections of $20 \mathrm{ml}$ saline every $12 \mathrm{~h}$ for 3 days (a) or $20 \mathrm{ml}$ bovine follicular fluid (bFF) every $6 \mathrm{~h}$ for 1 day (b) or $20 \mathrm{ml}$ bFF every $12 \mathrm{~h}$ for 3 days (c). Times of injections are indicated by arrows. Heifers were in oestrus within $24 \mathrm{~h}$ of peak levels of oestradiol. One heifer (b, O--O) was in oestrus 5, 6, 7, 8 and 9 days after PGF-2 $\alpha$. 
bFF for 1 day $(P<0 \cdot 025)$. In all groups, plasma levels of FSH increased again within $17 \cdot 5 \pm 1 \cdot 1 \mathrm{~h}$ (mean \pm s.e.m.; $\mathrm{N}=11$ ) after the preovulatory peak of $\mathrm{FSH}$ and remained elevated for $21 \cdot 5 \pm 2 \cdot 1 \mathrm{~h}$ (mean \pm s.e.m.; $N=11$ ). Concentrations of $\mathrm{LH}$ between 48 and $4 \mathrm{~h}$ before the surge were 1.4 times higher in heifers treated with bFF for 1 or 3 days than in control heifers $(P<0.05)$. However, concentrations of $\mathrm{LH}$ during and up to $48 \mathrm{~h}$ after the surge were not different among treatments $(P>0.05)$.

Effects of bFF on plasma concentrations of oestradiol and progesterone. Plasma concentrations of oestradiol in control heifers increased steadily between the time that PGF- $2 \alpha$ was injected and oestrus and were greater $(P<0.025)$ than in bFF-treated heifers by $18 \mathrm{~h}$ after PGF-2 $\alpha$ (Figs $4 \mathrm{a}, \mathrm{b}$, c). In heifers treated with bFF for 3 days, oestradiol did not increase until 4-6 days after PGF-2 $\alpha$ and peaked at oestrus. Similarly, in heifers treated with bFF for 1 day, oestradiol increased several days before oestrus and the preovulatory surges of LH and FSH. The magnitude of the delayed rise in plasma concentrations of oestradiol in bFF-treated heifers was not different from that in control heifers and resulted in relatively normal preovulatory surges of LH and FSH. One exception was a heifer treated with bFF for 1 day which showed persistent oestrous activity between 5 and 9 days after PGF-2 $\alpha$, had two peaks in plasma oestradiol at 5 and 8 days (Fig. 4) and failed to form a corpus luteum (Table 2).

Treatments with bFF did not affect plasma concentrations of progesterone during the oestrous cycle after treatment $(P>0.05$; data not shown) or alter the length of this oestrous cycle (Table 2 ), indicating that normal corpora lutea were formed (with the exception of one heifer described above).

\section{Discussion}

Treatment of heifers with injections of bovine follicular fluid after PGF-2 $\alpha$-induced luteolysis delayed the normal preovulatory increase in plasma concentrations of oestradiol and the onset of oestrus, suggesting that development and/or function of preovulatory follicles was inhibited during treatment. Plasma concentrations of FSH were suppressed during the injection period but basal concentrations of LH were unaffected, increasing similarly after luteolysis in treated and control heifers. These results suggest that $\mathrm{LH}$ alone is not sufficient to stimulate the normal development and/or function of the preovulatory follicle after luteolysis, but that FSH also plays a critical role.

The results of Exp. 2 are consistent with other reports in cattle that injections of follicular fluid selectively suppress plasma concentrations of FSH (Ireland et al., 1983; Braun et al., 1983; Johnson et al., 1985). In contrast, Johnson \& Smith (1985) reported that plasma concentrations of FSH were not decreased significantly during treatment of heifers with injections of follicular fluid on Days 1 through 5 of the oestrous cycle. However, treatment did delay the onset of oestrus after injection of PGF- $2 \alpha$ on Day 6 and there was a transient increase in FSH after treatment ended. These authors suggested that inhibin activity in the follicular fluid injections may have been insufficient to decrease FSH or that blood samples were not taken frequently enough (twice/day) to detect a decrease in FSH. In Exp. 1 of the present study, failure of follicular fluid to suppress FSH levels and to consistently delay oestrus in all heifers was probably due to an inadequate dosage of follicular fluid, since using twice the dosage in Exp. 2 delayed oestrus in all heifers. In contrast, Miller et al. (1979) reported that dosages of follicular fluid similar to those used in Exp. 1 consistently delayed oestrus to 8 or 9 days after PGF-2 $\alpha$ in all heifers.

Plasma concentrations of FSH in control heifers decreased after PGF-2 $\alpha$-induced luteolysis, in agreement with reports that levels of FSH decline during the follicular phase of normal oestrous cycles (Butler et al., 1983; Schallenberger et al., 1984). However, concentrations of FSH in follicular fluid-treated heifers were significantly lower and decreased earlier after PGF- $2 \alpha$ treatment than in control heifers. These findings are consistent with reports that treatment of cyclic ewes with bovine follicular fluid delayed the time from luteolysis to oestrus (Miller et al., 1979) and decreased plasma 
concentrations of FSH without changing basal concentrations and pulsatile secretion of LH (Miller et al., 1982; McNeilly, 1984). In monkeys, relatively small decreases in plasma concentrations of FSH induced by injections of pig follicular fluid during the follicular phase of the cycle impaired follicular development (Stouffer \& Hodgen, 1980; DiZerega et al., 1981; Channing, Anderson, Hoover, Gagliano \& Hodgen, 1981). It is likely that, in the present study, the small decrease in FSH during the follicular phase was sufficient to inhibit follicular development and delay oestrus despite the fact that basal plasma concentrations of LH increased normally after luteolysis and were slightly higher in follicular fluid-treated heifers than in control heifers during the 2 days before the preovulatory surges of gonadotrophins.

Plasma concentrations of oestradiol remained basal until several days after the last injection of follicular fluid in heifers treated for 1 or 3 days, indicating that development and/or function of preovulatory follicles was inhibited during treatment. Normal ovulatory follicles developed after treatments ended, since the increase in plasma concentration of oestradiol before oestrus was similar to that in control heifers and relatively normal surges of LH and FSH occurred on the day of oestrus. In addition, the length of the next oestrous cycle and plasma concentrations of progesterone during the luteal phase were normal, suggesting formation of functional corpora lutea. Experiments in vitro have demonstrated that FSH stimulates aromatization of androgen to oestradiol by granulosa cells of a variety of species (Richards, 1980). The results of the current study provide evidence in vivo that FSH is required for the preovulatory rise in plasma oestradiol.

The delay to oestrus and the preovulatory peaks of plasma gonadotrophins was more uniform in heifers treated with follicular fluid for 3 days ( 8 days after PGF-2 $\alpha$ ) than in those treated for 1 day $(4,5,6$ and 7 days after PGF-2 $\alpha$ ). One possible explanation for this difference is that, during the 3-day treatment, populations of follicles at stages of development earlier than the preovulatory follicle became atretic, reducing the number of follicles from which the preovulatory follicle could be selected. Treatment with follicular fluid for 1 day may have been too short to inhibit uniformly the prospective preovulatory follicle and/or induce atresia in less developed follicles. Therefore, a preovulatory follicle might have required more variable times to develop.

Within $24 \mathrm{~h}$ after the last injection of bovine follicular fluid in heifers treated for 1 or 3 days, plasma concentrations of FSH increased and remained elevated for 24-36 h. Increased levels of FSH after treatment with follicular fluid have been reported in rats (DePaolo, Hirshfield, Anderson, Barraclough \& Channing, 1979), sheep (Miller et al., 1982; McNeilly, 1984) and monkeys (Channing et al., 1981). DePaolo et al. (1979) suggested that endogenous production of inhibin may be low during treatment with follicular fluid due to inadequate stimulation of follicles with FSH, and that levels of FSH might increase after treatments are ended because the exogenous source of inhibin is removed. It was reported that in heifers the inhibin-like activity in follicular fluid of presumptive ovulatory follicles is higher than in atretic follicles and increases progressively during the $36 \mathrm{~h}$ after prostaglandin-induced luteolysis (Padmanabhan, Convey, Roche \& Ireland, 1984). In the present study it is likely that endogenous production of inhibin by the ovaries was decreased due to inhibition of preovulatory follicular development and/or function. In heifers injected with bovine follicular fluid every $6 \mathrm{~h}$ for 1 day (Exp. 2), levels of FSH increased before the last injection of bFF, suggesting that the pituitary may have become refractory to inhibition. A refractory response to bovine follicular fluid was reported for ewes (McNeilly, 1984) and was postulated to be due to reduced concentrations of oestradiol in plasma which might normally synergize with follicular fluid to inhibit FSH secretion. This is not an explanation for the results of the present study since plasma concentrations of oestradiol were reduced similarly in heifers treated with follicular fluid for 1 and 3 days, but a refractory response only occurred in heifers treated for 1 day.

On the day after the preovulatory surges of LH and FSH, plasma concentrations of LH returned to baseline but levels of FSH increased again in follicular fluid-treated and control heifers. The secondary increase in plasma FSH on the day after the gonadotrophin surges is consistent with previous reports for heifers (Walters \& Schallenberger, 1984), sheep (L'Hermite et al., 1972; 
Salamonsen et al., 1973; Pant, Hopkinson \& Fitzpatrick, 1977), hamsters (Bast \& Greenwald, 1974) and rats (Daane \& Parlow, 1971).

Although inhibition of preovulatory follicular development in heifers was clearly associated with decreased concentrations of plasma FSH, follicular fluid may have also inhibited folliculogenesis by a direct effect on the ovary. Follicular fluid contains a variety of substances which inhibit binding of FSH to granulosa cells in vitro (Fletcher, Dias, Sanzo \& Reichert, 1982; Sato, Ishibashi \& Iritani, 1982) and which inhibit follicular response to gonadotrophins in experiments in vivo (Kling et al., 1984; Cahill, Driancourt \& Findlay, 1984). From the results of the present study we cannot rule out the possibility that follicular fluid treatments may have had direct effects at the level of the ovary. However, the association of significant decreases in plasma FSH with a delay of oestrus and preovulatory follicular development suggests that in cattle FSH is required to support the growth and development of the preovulatory follicle.

We thank C. Berian, R. R. Saatman and S. E. Vincent for expert technical assistance; R. G. Cowan for advice on RIA procedures; H. Dormady for secretarial assistance; Dr W. R. Butler and Dr R. A. Milvae for their suggestions during preparation of the manuscript; and Dr D. J. Bolt of the USDA Animal Hormone Program and the National Hormone and Pituitary Hormone Program, and Dr L. E. Reichert, Jr and Dr G. D. Niswender for reagents used in the assays.

This study was supported by NIH grant HD- 14584 .

\section{References}

Bast, J.D. \& Greenwald, G.S. (1974) Serum profiles of follicle-stimulating hormone and prolactin during the estrous cycle of the hamster. Endocrinology 94, 1295-1299.

Beal, W.E., Milvae, R.A. \& Hansel, W. (1980) Oestrous cycle length and plasma progesterone concentrations following administration of prostaglandin F-2 $\alpha$ early in the bovine oestrous cycle. J. Reprod. Fert. 59, 393-396.

Bolt, D.J. \& Rollins, R. (1983) Development and application of a radioimmunoassay for bovine folliclestimulating hormone. J. Anim. Sci. 56, 146-154.

Braun, V.U., Schams, D., Buck, G. \& Leidl, W. (1983) Verlauf der FSH- und LH-blutplasmakonzentrationen und der zykluslänge beim rind nach applikation von boviner follikel- und zystenflüssigkeit. Zuchthygiene 18, 131-139.

Butler, W.R., Katz, L.S., Arriola, J., Milvae, R.A. \& Foote, R.H. (1983) On the negative feedback regulation of gonadotropins in castrate and intact cattle with comparison of two FSH radioimmunoassays. $J$. Anim. Sci. 56, 919-929.

Cahill, L.P., Driancourt, M.A. \& Findlay, J.K. (1984) Inhibition of folliculogenesis by ovine follicular fluid (oFF) in PMSG-treated ewes. Biol. Reprod. 30, Suppl. 1, 36, Abstr.

Channing, C.P., Anderson, L.D., Hoover, D.J., Gagliano, P. \& Hogden, G. (1981) Inhibitory effects of porcine follicular fluid on monkey serum FSH levels and follicular maturation. Biol. Reprod. 25, 885-903.

Channing, C.P., Anderson, L.D., Hoover, D.J., Kolena, J., Osteen, K.G., Pomerantz, S.H. \& Tanabe, K. (1982) The role of nonsteroidal regulators in control of oocyte and follicular maturation. Recent Prog. Horm. Res. 38, 331-400.

Daane, T.A. \& Parlow, A.F. (1971) Periovulatory patterns of rat serum follicle stimulating hormone and luteinizing hormone during the normal estrous cycle: effects of pentobarbital. Endocrinology 88, 653-663.

DePaolo, L.V., Hirshfield, A.N., Anderson, L.D., Barraclough, C.A. \& Channing, C.P. (1979) Suppression of pituitary secretion of follicle-stimulating hormone by porcine follicular fluid during pro-oestrus and oestrus in the rat: effects on gonadotrophin and steroid secretion, follicular development and ovulation during the following cycle. J. Endocr. 83, 355-368.

DiZerega, G.S., Turner, C.K., Stouffer, R.L., Anderson, L.D., Channing, C.P. \& Hogden, G.D. (1981) Suppression of follicle-stimulating hormone-dependent folliculogenesis during the primate ovarian cycle. $J$. clin. Endocr. Metab. 52, 451-456.

England, B.G., Niswender, G.D. \& Midgley, A.R., Jr (1974) Radioimmunoassay of estradiol-17 $\beta$ without chromatography. J. clin. Endocr. Metab. 38, 42-50.

Fletcher, P.W., Dias, J.A., Sanzo, M.A. \& Reichert, L.E., Jr (1982) Inhibition of FSH action on granulosa cells by low molecular weight components of follicular fluid. Molec. cell. Endocr. 25, 303-315.

Gill, J.L. (1979) Combined significance of nonindependent tests for repeated measurements. $J$. Anim. Sci. 48, 363-366.

Goodman, R.L., Reichert, L.E., Jr, Legan, S.J., Ryan, K.D., Foster, D.L. \& Karsch, F.J. (1981) Role of gonadotropins and progesterone in determining the preovulatory estradiol rise in the ewe. Biol. Reprod. 25, 134-142.

Grady, R.R., Charlesworth, M.C. \& Schwartz, N.B. (1982) Characterization of the FSH-suppressing activity in follicular fluid. Recent Prog. Horm. Res. 38, $409-447$.

Hansel, W. \& Convey, E.M. (1983) Physiology of the estrous cycle. J. Anim. Sci. 57, 404-424.

Ireland, J.J., Curato, A.D. \& Wilson, J. (1983) Effect of 
charcoal-treated bovine follicular fluid on secretion of $\mathrm{LH}$ and FSH in ovariectomized heifers. J. Anim. Sci. 57, 1512-1516.

Johnson, S.K. \& Smith, M.F. (1985) Effects of charcoal-extracted, bovine follicular fluid on gonadotropin concentrations, the onset of estrus and luteal function in heifers. J. Anim. Sci. 61, 203-209.

Johnson, S.K., Smith, M.F. \& Elmore, R.G. (1985) Effect of unilateral ovariectomy and injection of bovine follicular fluid on gonadotropin secretion and compensatory ovarian hypertrophy in prepubertal heifers. J. Anim. Sci. 60, 1055-1059.

Kling, O.R., Roche, P.C., Campeau, J.D., Nishimura, K., Nakamura, R.M. \& diZerega, G.S. (1984) Identification of a porcine follicular fluid fraction which suppresses follicular response to gonadotropins. Biol. Reprod. 30, 564-572.

Korenman, S.G., Stevens, R.H., Carpenter, L.A., Robb, M., Niswender, G.D. \& Sherman, B.M. (1974) Estradiol radioimmunoassay without chromatography: procedure, validation and normal values. $J$. clin. Endocr. Metab. 38, 718-720.

L'Hermite, M., Niswender, G.D., Reichert, L.E., Jr \& Midgley, A.R., Jr (1972) Serum follicle-stimulating hormone in sheep as measured by radioimmunoassay. Biol. Reprod. 6, 325-332.

McNatty, K.P., Gibb, M., Dobson, C. \& Thurley, D.C. (1981) Evidence that changes in luteinizing hormone secretion regulate the growth of the preovulatory follicle in the ewe. J. Endocr. 90, 375-389.

McNeilly, A.S. (1984) Changes in FSH and the pulsatile secretion of LH during the delay in oestrus induced by treatment of ewes with bovine follicular fluid. $J$. Reprod. Fert. 72, 165-172.

McNeilly, A.S., O'Connell, M. \& Baird, D.T. (1982) Induction of ovulation and normal luteal function by pulsed injections of luteinizing hormone in anestrous ewes. Endocrinology 110, 1292-1299.

McNeilly, A.S., Fraser, H.M. \& Baird, D.T. (1984) Effect of immunoneutralization of $\mathrm{LH}$ releasing hormone on LH, FSH and ovarian steroid secretion in the preovulatory phase of the oestrous cycle in the ewe. $J$. Endocr. 101, 213-219.

Miller, K.F., Critser, J.K., Rowe, R.F. \& Ginther, O.J. (1979) Ovarian effects of bovine follicular fluid treatment in sheep and cattle. Biol. Reprod. 21, 537-544.

Miller, K.F., Critser, J.K. \& Ginther, O.J. (1982) Inhibition and subsequent rebound of FSH secretion following treatment with bovine follicular fluid in the ewe. Theriogenology 18, 45-53.
Niswender, G.D., Reichert, L.E., Jr, Midgley, A.R., Jr \& Nalbandov, A.V. (1969) Radioimmunoassay for bovine and ovine luteinizing hormone. Endocrinology 84, $1166-1173$.

Padmanabhan, V., Convey, E.M., Roche, J.F. \& Ireland, J.J. (1984) Changes in inhibin-like bioactivity in ovulatory and atretic follicles and utero-ovarian venous blood after prostaglandin-induced luteolysis in heifers. Endocrinology 115, 1332-1340.

Pant, H.C., Hopkinson, C.R.N. \& Fitzpatrick, R.J, (1977). Concentrations of oestradiol, progesterone, luteinizing hormone and follicle-stimulating hormone in the jugular venous plasma of ewes during the oestrous cycle. J. Endocr. 73, 247-255.

Rahe, C.H., Owens, R.E., Fleeger, J.L., Newton, H.J. \& Harms, P.G. (1980) Pattern of plasma luteinizing hormone in the cyclic cow: dependence upon the period of the cycle. Endocrinology 107, 498-503.

Richards, J.S. (1980) Maturation of ovarian follicles: actions and interactions of pituitary and ovarian hormones on follicular cell differentiation. Physiol. Rev. 60, 51-89.

Salamonsen, L.A., Jonas, H.A., Burger, H.G., Buckmaster, J.M., Chamley, W.A., Cumming, I.A., Findlay, J.K. \& Goding, J.R. (1973) A heterologous radioimmunoassay for follicle-stimulating hormone: application to measurement of $\mathrm{FSH}$ in the ovine estrous cycle and in several other species including man. Endocrinology 93, 610-618.

Sato, E., Ishibashi, T. \& Iritani, A. (1982) Purification and action sites of a follicle stimulating hormone inhibitor from bovine follicular fluid. J. Anim. Sci. 55, 873-877.

Schallenberger, E., Schams, D., Bullermann, B. \& Walters, D.L. (1984) Pulsatile secretion of gonadotrophins, ovarian steroids and ovarian oxytocin during prostaglandin-induced regression of the corpus luteum in the cow. J. Reprod. Fert. 71, 493-501.

Stouffer, R.L. \& Hodgen, G.D. (1980) Induction of luteal phase defects in rhesus monkeys by follicular fluid administration at the onset of the menstrual cycle. $J$. clin. Endocr. Metab. 51, 669-671.

Walters, D.L. \& Schallenberger, E. (1984) Pulsatile secretion of gonadotrophins, ovarian steroids and ovarian oxytocin during the periovulatory phase of the oestrous cycle in the cow. J. Reprod. Fert. 71, $503-512$.

Received 17 June 1985 